\title{
Ti-Catalyzed Selective Isomerization of Terminal Mono-substituted Olefins
}

\author{
Hyung Soo Lee* and Gab Yong Lee

\begin{abstract}
Department of Chemistry, Catholic University of Daegu, Gyeongsan, Gyeongbuk 712-702, Korea. *E-mail: leeh@cu.ac.kr
\end{abstract} \\ Received November 16, 2004
}

Key Words : Isomerization, Olefin, Catalyst, $\mathrm{Cp}_{2} \mathrm{TiCl}_{2}$, Selectivity

\begin{abstract}
Transition metal complexes have been utilized in the homogeneous catalysis because of selectivity and catalytic activity under mild conditions. ${ }^{1}$ The isomerization of olefins catalyzed by transition metal complexes constitutes one of important type of reaction in organometallic chemistry. ${ }^{2}$ The isomerization of olefins occurs either by a metal hydride addition-elimination or by a $\pi$-allyl metal hydride intermediate. $^{2 \mathrm{~b}} \mathrm{HCo}(\mathrm{CO})_{4},\left[\left(\mathrm{C}_{2} \mathrm{H}_{4}\right)_{2} \mathrm{RhCl}\right]_{2}, \mathrm{Ni}\left[\mathrm{P}(\mathrm{OEt})_{3}\right]_{4}$, and $\mathrm{PtCl}_{2}\left(\mathrm{PPh}_{3}\right)_{2}-\mathrm{SnCl}_{2}$ are effective catalysts for isomerization of olefins via a metal hydride addition-elimination mechanism, ${ }^{3,4}$ and $\mathrm{Fe}_{3}(\mathrm{CO})_{12}$ catalyzed isomerization of 3-ethyl-1pentene and isomerization of 1-heptene catalyzed by $(\mathrm{PhCN})_{2} \mathrm{PdCl}_{2}$ occur via a $\pi$-allyl metal hydride mechanism. ${ }^{4,5}$ The cis/trans ratio of 2-butene obtained from isomerization of 1-butene by $\mathrm{RhH}(\mathrm{CO})\left(\mathrm{PPh}_{3}\right)_{3}$ has also been investigated. ${ }^{6}$ The skeletal isomerization of olefins catalyzed by $\left(\mathrm{R}_{3} \mathrm{P}\right)_{2} \mathrm{NiCl}_{2}$ is developed such as conversion of $\mathrm{cis}-1,4-$ hexadiene to trans-2-methyl-1,3-pentadiene. ${ }^{7}$ Titanium complexes serve as an effective catalysts for a variety of reactions such as hydroalumination, ${ }^{8,9}$ hydroboration, ${ }^{10}$ and hydrogenation ${ }^{11}$ of unsaturated hydrocarbons. We have been interested in the selective reactions of unsaturated hydrocarbons by using titanium and zirconium compounds. ${ }^{9-12}$ The reagent system composed of $\mathrm{LiAlH}_{4} / \mathrm{Cp}_{2} \mathrm{TiCl}_{2} \leq 2$ in the molar ratio promotes the isomerization of 1 -octene, ${ }^{8 \mathrm{~b}, \mathrm{~d}}$ but the detailed reaction for isomerization of olefins has not been reported. We report here a selective isomerization of olefins with low valent titanium complex generated from $\mathrm{Cp}_{2} \mathrm{TiCl}_{2}(\mathrm{Cp}=$ cyclopentadienyl $)$ and $\mathrm{LiAlH}_{4}$.
\end{abstract}

\section{Experimental Section}

All glassware used was predried in an oven, assembled hot and cooled with a stream of argon in glove box. All reactions were carried out under an argon atmosphere. All solvents were distilled and stored over an appropriate drying agent. $\mathrm{Cp}_{2} \mathrm{TiCl}_{2},{ }^{*} \mathrm{Cp}_{2} \mathrm{TiCl}_{2} \quad$ ( ${ }^{*} \mathrm{Cp}=$ pentamethycyclopentadienyl), and $\mathrm{LiAlH}_{4}$ were purchased from Strem Co., and used without further purification. All olefins were purified before use. ${ }^{1} \mathrm{H}$ NMR spectra were recorded in $\mathrm{CDCl}_{3}$ on Varian Gemini-200 spectrometer with tetramethylsilane as an internal standard. Infrared spectra were measured in a $\mathrm{KBr}$ pellet with a Matterson Genesis II FT-IR spectrophotometer. GC analyses were carried out with a Younglin GC-600D gas chromatograph equipped with HP-5 (Hewlett Packard, 0.32 $\mathrm{mm}, 30 \mathrm{~m}$ ) or BP-5 (SGE, $0.32 \mathrm{~mm}, 60 \mathrm{~m}$ ) capillary columns.
Mass spectra were obtained using a Shimadzu GC/MS QP5050.

Typical procedure for isomerization. The mixture of $\left(\mathrm{C}_{5} \mathrm{H}_{5}\right)_{2} \mathrm{TiCl}_{2}(0.251 \mathrm{~g}, 1.01 \mathrm{mmol}), \mathrm{LiAlH}_{4}(0.079 \mathrm{~g}, 2.08$ $\mathrm{mmol})$, and THF (15 mL) was placed in a vessel under an argon atmosphere. After stirring for $1 \mathrm{~h}$, allylbenzene $(2.508$ $\mathrm{g}, 21.2 \mathrm{mmol}$ ) was slowly introduced to the mixture at $0{ }^{\circ} \mathrm{C}$. The complete reaction was confirmed by GC, and the mixture was treated with dilute hydrochloric acid $(10 \mathrm{~mL})$ and extracted with $n$-pentane. The organic layer was dried over sodium sulfate, and the solvent was evaporated under reduced pressure. The residue was purified by column chromatography on alumina with $n$-pentane as an eluent, and $n$-pentane was removed to yield trans-1-phenyl-1propene $(1.728 \mathrm{~g}, 69 \%) .{ }^{1} \mathrm{H}$ NMR $\left(\mathrm{CDCl}_{3}\right): \delta 7.11-7.36(\mathrm{~m}$, $\left.5 \mathrm{H}, \mathrm{C}_{6} \mathrm{H}_{5}\right), 6.34(\mathrm{~d}, 1 \mathrm{H}, \mathrm{CH}), 6.16(\mathrm{~m}, 1 \mathrm{H}, \mathrm{CH}), 1.87(\mathrm{~d}, 3 \mathrm{H}$, $\left.\mathrm{CH}_{3}\right)$. IR $\left(\mathrm{cm}^{-1}\right): 3059,3024,2914,2853,1704,1601,1495$, 1443, 962, 735, 693 .

Preparation of 2,3-dibromo-2-methylbutane. To a solution of $\mathrm{LiAlH}_{4}(0.078 \mathrm{~g}, 2.06 \mathrm{mmol})$ and $\left(\mathrm{C}_{5} \mathrm{H}_{5}\right)_{2} \mathrm{TiCl}_{2}$ $(0.256 \mathrm{~g}, 1.03 \mathrm{mmol})$ in THF $(15 \mathrm{~mL})$ was added 3-methyl1-butene (1.410 g, $20.1 \mathrm{mmol})$. The reaction mixture was stirred at 0 for $1 \mathrm{~h}$. Excess bromine $(5.114 \mathrm{~g}, 32.0 \mathrm{mmol})$ in diethyl ether $(40 \mathrm{~mL})$ was added dropwise at $0{ }^{\circ} \mathrm{C}$. After completion of bromine addition, the reaction mixture was allowed to remain $0.5 \mathrm{~h}$ at room temperature. Then the mixture was washed with $10 \%$ sodium thiosulfate solution, and saturated sodium chloride solution. The organic layer was dried over magnesium sulfate, and the solvent was removed under reduced pressure. The residue was purified by column chromatography on silica gel ( $n$-hexane) to give 2,3-dibromo-2-methylbutane(3.060 g, 66\%). ${ }^{1} \mathrm{H}$ NMR: $\delta$ 4.43 (q, 1H CH), 1.92 (s. 6H, $\left.\mathrm{CH}_{3}\right), 1.85$ (d, 3H, $\left.\mathrm{CH}_{3}\right)$. IR $\left(\mathrm{cm}^{-1}\right): 2978,2926,2864,1375,1202,839,719,532$. Mass $\mathrm{m} / \mathrm{e} 228\left(\mathrm{M}^{+}\right), 230\left(\mathrm{M}^{+}+2\right), 232\left(\mathrm{M}^{+}+4\right)$.

The products were characterized by comparison with authentic samples using GC and spectral data.

\section{Results and Discussion}

We have studied the isomerization of representative olefins under the reaction conditions outlined in Table 1. As shown in Table 1, the isomerization of aliphatic terminal olefins such as 1-butene, 3-methyl-1-butene, and 1-octene occurred to give the desired compounds by bromination (entries 1 and 2) and hydrolysis (entry 4) at $0{ }^{\circ} \mathrm{C}$ in THF 
Table 1. Selective isomerization of olefins ${ }^{a}$

\begin{tabular}{|c|c|c|c|c|}
\hline Entry & Olefin & $\begin{array}{l}\text { Time } \\
\text { (h) }\end{array}$ & Product & $\begin{array}{l}\text { Yield } \\
(\%)^{b}\end{array}$ \\
\hline 1 & $\mathrm{CH}_{3} \mathrm{CH}_{2} \mathrm{CH}=\mathrm{CH}_{2}$ & 1 & $\begin{array}{c}\mathrm{CH}_{3} \mathrm{CH}-\mathrm{CHCH}_{3} \\
\mathrm{Br} \mathrm{Br}\end{array}$ & 96 \\
\hline 2 & $\left(\mathrm{CH}_{3}\right)_{2} \mathrm{CHCH}=\mathrm{CH}_{2}$ & 1 & $\begin{array}{c}\left(\mathrm{CH}_{3}\right)_{2} \mathrm{CH}_{\mathrm{Br}} \mathrm{CHCH} \\
\mathrm{Br}\end{array}$ & $96(66)$ \\
\hline 3 & $\mathrm{CH}_{3}\left(\mathrm{CH}_{2}\right)_{2} \mathrm{C}\left(\mathrm{CH}_{3}\right)=\mathrm{CH}_{2}$ & 3 & & 0 \\
\hline 4 & $\mathrm{C}_{5} \mathrm{H}_{11} \mathrm{CH}_{2} \mathrm{CH}=\mathrm{CH}_{2}$ & 1 & $\mathrm{C}_{5} \mathrm{H}_{11} \mathrm{CH}=\mathrm{CHCH}_{3}$ & $98^{\circ}$ \\
\hline $5^{d l}$ & $\mathrm{C}_{5} \mathrm{H}_{11} \mathrm{CH}_{2} \mathrm{CH}=\mathrm{CH}_{2}$ & 3 & $\mathrm{C}_{5} \mathrm{H}_{11} \mathrm{CH}=\mathrm{CHCH}_{3}$ & $42^{e}$ \\
\hline $6^{d}$ & $\mathrm{C}_{5} \mathrm{H}_{11} \mathrm{CH}=\mathrm{CHCH}_{3}$ & 5 & & 0 \\
\hline 7 & $\mathrm{PhCH}_{2} \mathrm{CH}=\mathrm{CH}_{2}$ & 1 & $\mathrm{PhCH}=\mathrm{CHCH}_{3}$ & $98^{\prime}(69)$ \\
\hline 8 & $\mathrm{CH}_{2} \mathrm{CH}=\mathrm{CH}_{2}$ & & $\mathrm{CH}=\mathrm{CH}$ & $97^{g}$ \\
\hline 9 & & & & $98^{h}$ \\
\hline 10 & $\begin{array}{l}\mathrm{CH}_{2} \mathrm{CH}_{2} \mathrm{CH}=\mathrm{CH}_{2} \\
\mathrm{CH}_{2} \mathrm{CH}_{2} \mathrm{CH}=\mathrm{CH}_{2}\end{array}$ & 1 & 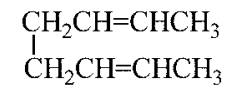 & 96 \\
\hline 11 & & 1 & & 95 \\
\hline
\end{tabular}

${ }^{a} \mathrm{Cp}_{2} \mathrm{TiCl}_{2}: \mathrm{LiAlH}_{4}$ : Olefin $=1: 2: 20$. Reaction performed at $0{ }^{\circ} \mathrm{C} .{ }^{b} \mathrm{GC}$ yields and numbers in parenthesis indicate isolated yields. ${ }^{c}$ trans $/$ cis $=$ $85 / 15 .{ }^{d *} \mathrm{Cp}_{2} \mathrm{TiCl}_{2}-\mathrm{LiAlH}_{4}$ was used. ${ }^{e}$ trans $/$ cis $=97 / 3 .{ }^{f}$ trans $/$ cis $=96 / 4$. ${ }^{g}$ trans $/$ cis $=95 / 5 .{ }^{h}$ trans $/$ cis $=97 / 3$.

under an argon atmosphere in an excellent yields. The reactivity of ${ }^{*} \mathrm{Cp}_{2} \mathrm{TiCl}_{2}-\mathrm{LiAlH}_{4}$ system was compared with that of $\mathrm{Cp}_{2} \mathrm{TiCl}_{2}-\mathrm{LiAlH}_{4}$ system in the isomerization of 1octene and 2-octene, respectively. When using ${ }^{*} \mathrm{Cp}_{2} \mathrm{TiCl}_{2}$ as the catalyst in the reaction of 1-octene, 2-octene (trans/cis = 97/3) was only obtained in low yield for $3 \mathrm{~h}$ (entry 5), but 2 octene was not isomerized even after $5 \mathrm{~h}$ (entry 6). As a detailed study, 1-octene and cis- and trans-2-octenes were isomerized in the presence of $\mathrm{Cp}_{2} \mathrm{TiCl}_{2}-\mathrm{LiAlH}_{4}$ under the same conditions, respectively. In the reaction of 1-octene, 2octene (trans/cis $=85 / 15$ ) as major product was obtained for $1 \mathrm{~h}$, but 3- and 4-octenes were detected in the product mixture for $3 \mathrm{~h}$. 2-Octene was gradually isomerized to 3 - and 4-octenes as time progresses. Production of 3- and 4-octenes could be attributed the reaction of the 2-octene with the catalyst to afford the more isomerization product. In case of cis-2-octene, trans-2-octene was obtained (36\%) with 3- and 4-octenes (9\%) for $5 \mathrm{~h}$, but reaction of trans-2-octene to cis2-octene hardly occurred. The results indicate that trans-2octene is produced from 1-octene as a major product in preference to the cis-2-octene in the initial stage of the reaction, and cis-2-octene gradually isomerizes to trans-2octene during the reaction. We examined the isomerization of 2,2-disubstituted olefin such as 2-methyl-1-pentene (entry 3 ), but this olefin was not isomerized at $0{ }^{\circ} \mathrm{C}$ even after $3 \mathrm{~h}$. Aromatic olefins such as allylbenzene, allyl anisole, and safrole were smoothly isomerized to the corresponding internal olefins in excellent yields (entries 7, 8, and 9). When the reaction of 1-octene, allylbenzene, and safrole was investigated at $0{ }^{\circ} \mathrm{C}$ to examine the selectivity for this system (entries 4, 7, and 9), the trans-isomers were predominantly obtained. This system shows very good selectivity toward mono-substituted terminal olefns. The reagent system was applied to dienes such as 1,7-octadiene and 1,5-cyclooctadiene to produce 2,6-octadiene and 1,3-cyclooctadiene, respectively (enties 10 and 11). Thermal treatment of organoboranes converts internal olefins into terminal olefins via the contrathermodynamic isomerization of olefins. ${ }^{13}$ Therefore, the isomerization of 2-octene and $\beta$-methylstyrene was tried to convert internal olefins into terminal olefins by heating, but these reactions were not achieved. The isomerization of olefins catalyzed by $\mathrm{Cp}_{2} \mathrm{TiCl}_{2}-\mathrm{LiAlH}_{4}$ system is presumed to proceed via the thermodynamic stability. The scope of the catalytic reaction and applicability for organic syntheses are now under study.

\section{References}

1. (a) Nakamura, A.; Tsutsui, M. Principle and Application of Homogeneous Catalysis; Johon Wiley \& Sons: New York, 1980. (b) Lee, S.: Jung, H. R.: Kim, K. M.; Song, C. E.; Cho, C. G. Bull. Korean Chem. Soc. 2003, 24, 1407.

2. (a) Yamamoto, A. Organotransition Metal Chemistry; Johon Wiley \& Sons: New York, 1986; pp 372-374. (b) Crabtree, R. In The Organometallic Chemistry of the Transition Metals; John Wiley \& Sons: New York, 1988; pp 188-190. (c) Han, S. G.; Park, S. S.; Lee, M. H.; Park, H. K. Bull, Korean Chem. Soc. 2004, 25 , 106.

3. (a) Taylor, P.; Orchin, M. J. Am. Chem. Soc. 1971, 93, 6504. (b) Cramer, R.; Lindsey, R. V. J. Am. Chem. Soc. 1966, 88, 3543. (c) Tolman, C. J. Am. Chem. Soc. 1972, 94, 2994. (d) Adams, R.; Batley, G.; Bailar Jr., J. J. Am. Chem. Soc. 1968, 90, 6051.

4. Casey, C.; Cyr, C. J. Am. Chem. Soc. 1973, 95, 2248 and references cited therein.

5. Harrod, J.; Chalk, A. J. Am. Chem. Soc. 1966, 88, 1521.

6. (a) Nakamura, A.; Tatsumi, K.; Otsuka, S. J. Mol. Catal. 1976, 1, 417. (b) Evans, D.; Osborn, J.; Wilkinson, G. J. Chem. Soc. A 1968, 3133 .

7. (a) Miller, R.; Pinke, P.; Stauffer, R.: Golden, H.; Baker, D. J. Am. Chem. Soc. 1974, 96, 4211. (b) Pinke, P.; Miller, R. J. Am. Chem. Soc. 1974, 96, 4221. (c) Pinke, P.; Stauffer, R.: Miller, R. J. Am. Chem. Soc. 1974, 96, 4229.

8. (a) Sato, F.; Sato, S.; Sato, M. J. Organometal. Chem. 1976, 122, C25. (b) Isagawa, K.; Tatsumi, K.; Otsuji, Y. Chem. Lett. 1976, 1145. (c) Sato, F.; Sato, S.; Sato, M. J. Organometal. Chem. 1976, 122, C25. (d) Isagawa, K.; Tatsumi, K.; Kosugi, H.; Otsuji, Y. Chem. Lett. 1977, 1017. (e) Sato, F.; Sato, S.; Sato, M. J. Organometal. Chem. 1977, 131, C26. (f) Isagawa, K.; Tatsumi, K.; Otsuji, Y. Chem. Lett. 1977, 1117. (g) Sato, F.; Tomuro, Y.; Ishikawa, H.; Sato, M. Chem. Lett. 1980, 99.

9. (a) Lee, H. S. Bull. Korean Chem. Soc. 1987, 8, 484. (b) Lee, H. S.; Kim, I. H. J. Korean Chem. Soc. 1993, 37, 689.

10. (a) Lee, H. S.; Isagawa, K.; Otsuji, Y. Chem. Lett. 1984, 363. (b) Lee, H. S.; Isagawa, K.; Toyoda, H.; Otsuji, Y. Chem. Lett. 1984, 673.

11. (a) Lee, H. S. J. Korean Chem. Soc. 1988, 32, 79. (b) Lee, H. S.; Lee, H. Y. Bull. Korean Chem. Soc. 2000, $21,451$.

12. Lee, H. S.; Kim, C. E. J. Korean Chem. Soc. 2003, 47, 297.

13. Brown, H. C. Organic Synthesis via Boranes; John Wiley \& Sons: New York, 1975; pp 77-80. 